\title{
Er en kombinations- bachelor fx HA(psyk.) et godt svar på relevante problemer i senmoderniteten?
}

\author{
Mads Hermansen, professor, dr. paed. Learning Lab, CBS
}

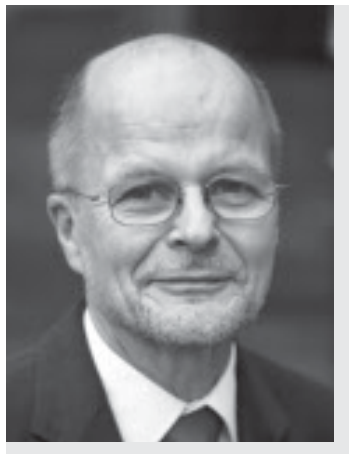

Mads Hermansen, professor, dr pæd.

Copenhagen Business School \& Nordiska högskolan för Folkhälsovetenskap i Göteborg. Arbejder især med organisations udvikling, læring, personlighedsudvikling, udviklingsarbejde i organisationer og universitetspædagogik.

Litteratur:

- Omlæring. Klim 2003. 2. oplag 2006. Engelsk udgave: Relearning (2005). CBS Press \& Danmarks Pædagogiske Universitets forlag. København

- Kommunikation og samarbejde - i professionelle relationer. Sammen med O. Løw \& V. Petersen (2004). Alinea 2. oplag 2005, 3. oplag 2006, 4. og 5. oplag 2007.

- Didaktikken og individet - når senmoderne elever skal lære (2005). Sammen med E. Jensen og J. Krejsler. Alinea.

- Narrative, Culture and Learning (2006). Together with Jerome Bruner, Carol Feldman \& J. Molin. New Social Science Monographs. Copenhagen. (1 5 p.)

- Læringsledelse. Løft til læring i skolen (2007). Sammen med F. B. Andersen, B. Ryberg, A. H. Jensen, V. Petersen, \& K. Bro. Samfundslitteratur.

\section{Reviewet artikel}

Samspillet mellem samfundsudvikling og universiteternes svar på udfordringer herfra udkrystalliserer sig hele tiden. På CBS har man i en rakke år udviklet kombinationsuddannelser mellem erhvervsøkonomi og forskellige samfundsvidenskabelige og humanistiske discipliner som svar på denne udfordring. I 2003 så $H A$ (psyk.) dagens lys. I artiklen belyses to markante elementer i studiet: Narrativet (historiefortalling) om studiets opbygning, den studerendes dannelsesproces og virksomhedens tilblivelsesproces og gruppedannelsesprocesserne, som tager udgangspunkt $i$ testning af stil, samarbejdsprofil og -trak.

Denne overskrift kan på en vis måde siges at være metaoverskrift over en række artikler, bøger og oplæg om læring og udvikling af undervisning, som jeg igennem de sidste par år har beskæftiget mig med og fortsat vil i de kommende. ${ }^{1}$ Opgaven har fra begyndelsen handlet om, hvordan man i konstruktionen af nye uddannelser făr forfulgt en række presserende opgaver i forhold til det at skabe tidsadækvate tilbud. Her vil jeg illustrere med to aspekter. Det forste handler at forbinde uddannelser med tilværelsesprojekter. Det andet om gruppedannelsesprocessen, som vi har valgt at lade den forløbe på et studie på Handelshøjskolen i København. Her er progression og mimen mulighed for at fă indflydelse på, hvem man arbejder sammen med, den røde tråd.

Hvorfor er det nu vigtigt? En række diskussioner har næsten fast dagsorden på uddannelsesområdet, bl.a. om hvordan man indretter uddannelsesbilledet, så det matcher de til enhver tid mest æedruelige opfattelser af, hvad de næste generationer af uddannede skal have af kvalifikationer. Diskussionerne går også på, hvordan man møder den ungdomsårgang, som til enhver tid ikke helt ligner den foregående, men hvor undervisere og uddannelsesadministratorer naturligt har tendens til hele tiden at tilrettelægge $i$ lyset af det forløb, man selv 
uddannelsesmæssigt var igennem. I den forstand handler det om undersøgende, med egen bagages tendens til at fylde for meget, alligevel at bringe denne bagage i spil med de stadigt forandrende forhold.

Narrativet om tilværelsesprojektet og processerne med kvalificering til at indgå i teamwork (gruppedannelse) er efter min opfattelse eksemplariske til belysning af, hvordan man kan arbejde med aktuelle temaer i samfundsudviklingen. Det gruppedannelsesmæssige fylder meget. Det betyder ikke, at det er det vigtigste, men alene at det i denne sammenhæng kræver mere plads for adækvat at blive foldet ordentligt ud.

Denne artikel vil altså tage fat på beskrivelses- og analysemæssigt at illustrere udvikling af HA(psyk.) som en akademisk bachelor på Handelshøjskolen i København (CBS), som i hvert fald forfølger følgende formål:

- At skabe god begyndelse på et uddannelsesforløb med rum og retning både $i$ forhold til det at afslutte sig alene med bachelorforløbet og til det at fortsætte en akademisk karriere på kandidatniveau

- I forhold til begge ovenstående scenarier at skabe mest optimal kompetence i forhold til afstigning efter bachelorforløb, men også at skabe relevante afsæt for fortsættelse på kandidatniveau

- At indrette uddannelsen så den de facto tager udgangspunkt i de personlige, sociale og faglige kompetencer de unge kommer med

- At skabe en akademisk bachelor som eksplicit tager udgangspunkt $\mathrm{i}$ arbejdet med at give de studerende en erhvervskvalificering

Jeg vil ved eksempler fra studieplan og oplæg til studieaktiviteter $i$ to spor - et narrativt og et socialt - antyde, hvordan den pædagogiske og uddannelsesmæssige tænkning er under udkrystallisering på studiet.

Jeg kunne for så vidt godt have valgt alle mulige andre synsvinkler til illustration, $\mathrm{x}$ vores måde at tilrettelægge eksamen eller at udfolde det tværfaglige grundlag mere detaljeret, end jeg får gjort. Når det narrative og sociale eksponeres, er det imidlertid fordi de på særligt eksemplarisk vis egner sig til (i deres sammenflettethed) at vise det særlige $i$ vores koncept, samtidig med at jeg forfølger det generelle, som i den grad også er på dagsordenen i denne sammenhæng, nemlig at fange den kiasme, som forener samfundsudvikling og dermed forbundet personlighedsudvikling i senmoderniteten med relevante uddannelsestænkninger.

Det er min robuste påstand, at unge i senmoderniteten på en række områder er meget forskellige fra ungdomsårgange, som de så ud for 20 og 30 år siden (Simonsen 1998; Simonsen 1999; Illeris 2000; Ziehe \& Stubenrauch 1983). I kort form kan det som påstande anføres at:
- De generelt har større tro på, at de er ønskede og har ret til at være en del af den sammenhæng, de kommer ind i, når de begynder studiet end tidligere generationer af studerende

- De er præget af et større forventningspres fra omgivelserne og dermed pres på egne forventninger om, at deres succes er personafhængig

- De er præget af store forventninger om, at andre skal servicere dem

- De ofte har urealistiske forventninger til forholdet mellem deres egen indsats i samspillet med medstuderende og undervisere

- De agerer mere paradoksalt i en pendlen mellem 'ikke at ville finde sig i noget' og 'relativt uproblematiseret at indordne sig'.

Det er bl.a. med sådanne generelle antagelser, at HA(psyk.) i 2001-02 blev konstrueret i en arbejdsgruppe nedsat af dekanen for Det erhvervsøkonomiske fakultet på CBS. Uddannelsen skulle med udgangspunkt i bekendtgørelsen om erhvervsøkonomiske bacheloruddannelser skabe mulighed for en samtænkning af psykologi og erhvervsøkonomi.

\section{Uddannelsens formål blev således udkrystalliseret:}

"\$ 1. Bacheloruddannelsen i erhvervsøkonomi/psykologi, HA(psyk.), er en integreret videregående uddannelse, der sigter mod at uddanne bachelorer som formår at tilføre et psykologisk perspektiv til virksomhedens forskelligartede erhvervsøkonomiske opgaver og problemstillinger.

Stk. 2. Uddannelsen skal gøre det muligt for den studerende at udvikle kompetencer, der kan medvirke til at styrke kvaliteten $\mathrm{i}$ interpersonelle relationer og processer forbundet med virksomhedens almindelige opgavevaretagelse.

$\$ 2$. Uddannelsen tilsigter at give dimittenderne umiddelbar erhvervskompetence. Den tilsigter endvidere at kvalificere de studerende til videregående studier på de erhvervsøkonomiske kandidatuddannelser«

(studieordningen for HA(psyk.) 2004).

\section{Studiets opbygning}

HA(psyk.) er en uddannelse bygget over den enkelte studerendes historiefortællende konstruktion i samspil med lærere og medstuderende af erhvervsidentitet og af relevante videnskabeligt funderede faglige kompetencer.

Studiet er derfor bygget op som et narrativ, hvor der jo som bekendt skal være en begyndelse, en afslutning en midte og et plot (se fx Ricæur 2002; Hermansen 2001). Det vil sige, at studiet skal skrive sig ind i en individuel historiefortælling, hvor kompetenceudvikling og identitet går hånd $\mathrm{i}$ hånd, men hvor denne del af fortællingen knyttes tæet til virksomhedens eller 
organisationens opbygning efter samme skabelon. Men da jeg ikke kan forvente, at den narrative vinkling er alment kendt, er her lidt mere om den:

\section{Historiens ramme}

At fortælle en historie er at iscenesætte en mulig handling. Det kræver opstilling af en scene, hvor denne handling kan udspilles.Vi skal have en, der handler - en aktør/agent. Derudover skal vi have en handling - et mål - en ramme - et værktøj til løsning af problemet eller handlingen eller en mulig løsning af vanskeligheden (Burke 1945).

At fortælle historier med en agent, mål, ramme, midler og konflikter er i sig selv en meningsdannelse allerede ved udvælgelse og synsvinkelsættelse.

Udsigelsen kommer til at kursivere det, der allerede er udvalgt. Bevægelsen går fra

- fortrængt (ikke fortalt), til

- anet (forberedt med henblik på at blive fortalt) til

- indsigt (fortalt i egen medlytning), til

- bevidsthed (reflekteret og forskelligt synsvinkelsat i fælles undersøgelse og forundring

\section{Krav til historien}

Uanset reference til verden og uanset hvordan man forholder sig til sprog-verdensreferencen, så er troværdigheden af det fortalte meget afhængig af, på hvilken måde historien fortælles. Kenneth G. Gergen sætter i sin bog Virkelighed og relationer (1997) en række krav op, som ikke er almengyldige, men ret almindelige til gode narrativer. Han siger:

- Der skal være en ordentlig slutning.

- Udvælgelse af begivenheder som er relevante for slutmålet.

- Ordning af begivenhederne.

- Identiteters stabilitet

- Årsagssammenhænge og

- Demarkationstegn.

(Gergen 1997, p. 194-196)

De første tre punkter er der ikke problemer med umiddelbart at identificere indholdet i, men 'Identiteters stabilitet'? Hermed menes, at den velformede beretning fremstiller sig selv som sammenhængende i identitet over tid, altså at det er den samme identitet, der fortælles fra og om. Demarkationstegn er bestemte rammesættende signaler til identifikation af $f x$ genre. - Der var engang... - Har du hørt den om...? er sådanne demarkationstegn. Jeg tror, det er rigtigt, at jo mere man kan opfylde lytterens ønske om en velformet historie, jo mere vil historien blive accepteret som sand. Ud fra denne antagelse er det så også lettere at forstå, hvorfor nogle kommer godt af sted med de mest vidtløftige usandsynligheder, mens andre bliver benhårdt knaldet på nøgternhed. Det kunne forlede en til at tro, at det alene var ramme og iscenesættelse af historien, som betød noget for troværdigheden af historien.

Med denne korte introduktion til historiefortælling, som man i øvrigt kan læse meget mere om andetsteds (Hermansen 1999; 2001), er det formodentligt relativt indlysende, at opbygningen af de enkelte semestre på HA(psyk.) ser ud som følger:

1. semester. Indledning

2. semester. Virksomhedens udviklingsprocesser

3. semester. Virksomhedens styringsprocesser

4. semester. Virksomhedens analyseprocesser

5. semester. Virksomhedens kommunikationsprocesser.

6. semester. En afslutning

I kort form kan man ellers om studiet hævde følgende:

Den nye bacheloruddannelse udmærker sig ved at være reelt eller funktionelt tværfaglig, dvs. der anlægges en tematisk synsvinkel på fagblokkene. Man kan skelne mellem flere forskellige former for tværfaglighed. I den mere kuriøse ende af feltet, men langt fra ikkeeksisterende, er formen: Fagligt sammenskudsgilde, hvor man tager lidt af det ene og lidt af det andet, som man nu umiddelbart kan se fornuft i. Men også formel tværfaglighed eller flerfaglighed hører til her i den kuriøse ende af skalaen. Formel tværfaglighed kan $\mathrm{fx}$ være integration af et fags metoder med et andet fags indhold, eller at man tager elementer fra forskellige fag og bringer dem sammen, fordi de tilsyneladende har noget med det samme at gøre. Et eksempel fra erhvervsøkonomi og psykologi kunne være, at man belyste temaet aktiemarkedet ved at introducere de studerende til økonomiske teorier om markeder (udbud og efterspørgsel) og samtidig introducerede dem til socialpsykologiske teorier om holdningsdannelse, rollemodeller og forventningsdannelse. Temaet markedet lader sig naturligvis let illustrere både økonomisk og psykologisk på denne måde, men hvis de forskellige synsvinkler ikke sættes $\mathrm{i}$ forbindelse med en konkret brug eller et problem, som skal analyseres eller forstås, overlades den konkrete tværfaglighedsintegration til alene at foregå i de studerendes hoveder. Her skal den naturligvis i sidste instans udkrystalliseres, men før det kan ske frugtbart, er det, for at den kan blive til funktionel tværfaglighed (som må være enhver tværfagligheds mål), nødvendigt, at der sker konkrete konstruktioner i undervisningens rum. ${ }^{2}$ Læring foregår for at blive til læring altid to gange. Første gang i det sociale rum, hvor man er sammen (reelt eller virtuelt) om socialt at konstruere sammenhængsforståelserne. Anden gang sker det $i$ hovedet på den studerende.

Ud over denne markante tværfaglige profil, hvor tværfagligheden hele tiden undersøges $\mathrm{i}$ forhold til konkrete fænomener i virksomheden, har uddannelsen også en markant induktiv profil, hvilket indebærer et meget pragmatisk, funktionelt og praksisrettet studieforløb baseret på et stort omfang af øvelser og laboratorie- og casearbejde.

Uddannelsens fundament er erhvervsøkonomien, og den rummer ingen undervisning i terapeutiske pro- 
cesser og eksistentielle kvaler. Men de studerende får selvfølgelig viden om de hjælpeforanstaltninger, der findes til brug for medarbejdere i nød og krise. De lærer om dynamikken i gruppeprocesser og konfliktløsning, og de bliver i stand til at navigere i den jungle af kurser og efteruddannelse, der tilbydes erhvervslivet. Der produceres bachelorer, der kan orientere sig i kaos og tænke mulighedsåbnende og problemløsende i spændingsfeltet mellem psykologi og økonomi med enkeltfagligt udgangspunkt i fagene.

Med fokus på virksomheders udviklingsprocesser, styringsprocesser, analyseprocesser og kommunikationsprocesser kan HA(psyk.) betegnes som en slags genvej til erhvervs- og organisationspsykologien. $\mathrm{Og}$ uddannelsen giver kompetence til at deltage i løsningen af mange forskellige opgaver med et psykologisk perspektiv, fx. som HR-manager, uddannelsesplanlægger, projektleder, proceskonsulent eller med kommunikation og branding. I det følgende vil jeg for at highlighte uddannelsens specialitet koncentrere mig om to gennemgående elementer: Det personlige narrativ og gruppedannelsesprocessen, for på den måde at eksponere og diskutere de elementer, som er beskrevet ovenfor og som efter mine overbevisning gør denne induktivt prægede uddannelse til et tidssvarende bud på, hvordan man kan strukturere og indholdsbelægge en uddannelse, så den for så vidt gør en dyd af de forandringer, der er sket med samfundet og med den ungdom, som starter et bachelorforløb.

\section{Det personlige narrativ}

Udannelsens indledning består af tre miniforløb. I overskrift hedder de: Narrativet, Læreprocessen og Identitetsdannelse. I alle tre tilfælde er der tale om at lægge en erhvervsøkonomisk vinkel via virksomheden og en psykologisk via det personlige, ind over temaerne. I det første forløb arbejdes der med forskellige narrative teoretikere fx Bruner (1999) og Ricæur (2002), ligesom der arbejdes med praktisk eksponering af fortællingens kraft i øvelser.

Et eksempel på en øvelse er følgende: Man sidder i rundkreds og begynder øvelsen med at diskutere, hvilken organisation man er. Når det er besluttet, tager man første runde med præsentation af sig selv som medarbejder eller del af ledelsen. Samtidig kommer man med et udsagn om noget på virksomheden. Gennem fortællingen skabes en virksomhed ved i gentagende runder med udsagn dels at sige noget nyt, men også at forholde sig til de tidligere udsagn. Første forløb afsluttes med opgaven om at danne et personligt narrativ, hvor man får følgende opdrag:

"Med udgangspunkt $i$ det faktum at $d u$ har sogt ind på $H A(p s y k$.) og er blevet optaget på studiet, er det formålet med denne opgave at du gor dig overvejelser over sammenhangen mellem dit tilvarelsesprojekt indtil nu og din forestilling om, hvordan dette projekt skal udvikle sig.
Opgave: Du skal på maks. 5 sider forholde dig til, hvilke forhold $i$ dit liv, som har fort dig til at soge optagelse på HA(psyk.) på CBS. Du må gerne inddrage de overvejelser, du gjorde dig under introforlobet, hvor I også arbejdede med det personlige narrativ. Du skal gore dig overvejelser over samspillet mellem de historiske faktorer, der er indgået $i$ dine overvejelser over at søge CBS, og det du forestiller dig, der kommer til at ske i lobet af de tre års bachelorstudium. Kort sagt, hvad bragte dig her, hvad er din forestilling om de tre noeste år, og hvor vil det bringe dig hen? Du skal fokusere på de karrieremassige aspekter $i$ dit tilvarelsesprojekt. Du skal begrunde og argumentere for deres relevans og tilstrebe en beskrivende, distanceret og analyserende form, hvor $d u$ fokuserer på de vigtigste forhold. Narrativet skal ikke vare en privat bekendelsesberetning, men gerne en fagpersonlig og psykologisk begrundet analyse. Derudover skal du analytisk begrundet satte dit narrativ ind $i$ en teoretisk ramme (narrativ, socialkonstruktion, samtidsanalytisk litteratur el. lign.), hvor du kan hente materiale til denne del af arbejdet fra den vejledende litteratur til forste laboratorieforløb.

Bedommelsen af opgaven vil tage udgangspunkt $i$ de kvalitetskriterier, som er formuleret $i$ opgaven.

Opgaven bedommes godkendt/ikke godkendt af underviserne i psykologi.

I forbindelse med dit bachelorprojekt på 6. semester beder vi dig om at se tilbage og reflektere over dit forlob fra det narrativ, du formulerede her på 1. semester og frem mod det, du forteller på 6. semester. Din refleksion over dit eget narrativ vil indgå $i$ bedommelsen af bachelorprojektet."

For måske at forstå lidt af begrundelsen for, at vi formulerer opgaven sådan, er jeg nødt til ganske kort at introducere til den læringsopfattelse, som ligger under studiets opbygning. Den ultrakorte udgave ${ }^{3}$ af denne opfattelse har jeg formuleret $i$ 'Voksenpædagogisk opslagsbog' (Hermansen 2005). Det lyder således:

\section{"En narrativ samtonkning af loeringssynspunkterne}

Når vi leerer noget, foregår det altid $i$ konkrete situationer, $i$ 'nuer' hvor det vi har med fra vores liv, vores historie, moder forestillingerne om det, der er på vej. Eller sagt på en anden måde vi laerer hele tiden $i$ spandingsfeltet mellem feedback, det der er sket og feedforward, det vi har forventning om vil ske. Feedback kan beskrives efter principper $i$ operant betingning (belonning giver positiv feedback til det 'hensigtsmaessige'). Feedforward kan beskrives efter principperne i klassisk betingning (noget kobles med noget andet og giver derved mulighed for i fremtidige situationer at forudse, forudforstå eller foretage 'feedforward' af noget, som vil folge af noget). Fx når et barn af sin mor leerer at fà en araknofobi (panikangst for edderkopper). Det kan ske ved, at moren tydeligt viser sin angst ved synet af edderkopper. Barnet laerer på den måde, at angst og edderkopper horer sammen. Laringen kaldes også for 'signallaring', fordi edderkoppen $i$ dette tilfalde bliver laert som det signal, som udloser angst.

Megen loering foregår automatisk, uden at vi egentligt registrerer, at vi laerer. Man kan sige, at laringen med et fag- 
udtryk er 'habituel' eller mere dagligdags, at den foregair som automatisk vanelaring. Men laringen kan også vare refleksiv. Det bliver den mere eller mindre automatisk, når vi ikke kan komme igennem med at lare noget på et vaneniveau. Det er $f x$ det der sker $i$ omstruktureringen, som den beskrives $i$ kognitiv lacing, $i$ systemisk eller social konstruktionistisk laring. Udspoendtheden mellem habituel-og refleksiv loering er altså det andet begrebspar vi kan forstå loring $i$ forhold til.

Det tredje begrebspar til beskrivelse er laring som 'møje' og laring som 'overskud'. Laring som moje er af de fleste velkendt. Det er her stoffet eller laringssituationen giver så store problemer, at laeringen foregår langsomt og besverligt. Meget stof skal igennem en møje proces for at blive lart. Overskud refererer til den form for laring, hvor flow, optagethed og eksperimentering med muligheder gor laringen til en leg. Ofte er overskudslaring netop også noget, der kommer af leg.

Disse tre begrebspar giver $i$ kombination mulighed for at forstå laceprocessen som noget, der er indskrevet i en fortsat meningskonstruktion, hvor der er to aktivt ordnende principper - et 'paradigmatisk' og et 'narrativt', hvor det forste er funktionelt $i$ forhold til 'forklaring' af naturen, og det sidste er funktionelt i forhold til 'forståelse' af menneskers liv (jvf. Bruner 1999).

Det er min påstand, at man med disse tre begrebspar: Feedback/feedforward, Habitus/refleksion og Møje/overskud kan identificere de delkomponenter i laringen, som sammen med den sociale kontekst fyldestgørende kan bruges til at forstå og forklare laringsprocessens dynamik. "

Som man kan se, forsøger jeg med min teoretiske konstruktion at gribe om og integrere $\mathrm{i}$ hinanden forholdet mellem det paradigmatiske, det narrative og læreprocessen ud fra en opfattelse af, at disse faktorer alle skal være med for at skabe den sammenhæng af faglighed (paradigmatisk viden), den enkeltes forståelse af hvordan det hænger sammen også med livet i bred forstand (narrativt struktureret) og så læreprocesteoriens understregning af, hvordan læring altid foregår i et udspændt rum omkring nuet som feedback, feedforward, habituelle, refleksive, overskuds- og møjeprocesser.

I studieordningen står der bl.a. »Projektet skal endvidere trække en linie tilbage til 1. semesters arbejde med det personlige narrativ og de skift i perspektiv og synsvinkler, som er opstået undervejs i studiet fra slutningen af 1. semester til påbegyndelsen af bachelorprojektet« (Studieordningen HA(psyk.) 2004). Udspændtheden mellem 1. semesters opgaven og afsløjfningen på 6 . semester holder således dagsordenen fast, for så vidt angår det fortsatte konstruktive arbejde med at skabe sin identitet som HA(psyk.)'er. Det aktive konstruktionsarbejde tager eksplicit udgangspunkt i narrativ læringsteori, som det fx er formuleret i Hermansen (2003g). Arbejdet kan kort karakteriseres som det eksplicitte arbejde med de studerendes professionsudvikling gennem tilegnelse af forskellige kompetencer relateret til udvikling, styring, analyse og kommunikation, som holdes sammen i det udspændte narrativ fra begyndelse til afslutningsprojektet. Det sker ved i historiens midte at give hjælp til identifikation af de meningsgivende pointer, som netop handler om at blive praksiskompetente eller som Schön ville formulere det, at blive 'en reflekteret praktiker' (Schön 2001).

\section{Diskussion af Narrativet}

Sammenhængen mellem det indledende narrativ i 1 . laboratorieforløb og den aktive forholden sig, som den studerende skal udfolde på sit eget narrativ i bacheloropgaven på 6. semester har bl.a. følgende begrundelser: Det personlige tilværelsesprojekt (Bertelsen 1994, Hermansen 2003g) er som rød tråd i dannelsesprocessen i takt med den samfundsmæssige udvikling blevet mere centralt. Det hænger naturligvis bl.a. sammen med den mangfoldighed af valgmuligheder som qua nyudviklede teknologier inden for kommunikation og produktion har medført, at det enkelte menneske i sin orientering i sit eget tilværelsesprojekt paradoksalt står med noget, der ligner et dilemma. Det kan beskrives som forholdet mellem de mange muligheders åbning og de dermed forbundne næsten lige så mange muligheders lukning, når man først har valgt retning. Valgets ubærlighed bliver på den måde et meget større pres, når muligheder mangfoldiggør sig. For dem, som relativt målrettet og suverænt kan orientere sig i mangfoldigheden, er dette naturligvis en mulighedsåbning, som er en gave, men for den usikre (uanset hvoraf usikkerheden kommer) er det en barriere, som kan være svær at overvinde.

I den læringsterminologi (Hermansen 2002d) jeg ofte benytter mig af, når jeg beskriver den slags forhold, kalder jeg det forholdet mellem betydning og mening, hvor betydning henviser til det fænomen, som netop tydeliggør sig, påkalder sig interesse og opmærksomhed, mens mening henviser til det fænomen, at man får ordnet betydninger i helheder, i systemer, eller som jeg grundlæggende forstår det i narrativt strukturerede fortællinger om, hvorfor noget er vigtigere end noget andet, og derfor hjælpsomt gør det muligt at prioritere mellem det vigtige og det mindre vigtige. Ubeslutsomheden er i denne terminologi en dvælen i betydningerne. Enhver betydning kalder imidlertid umiddelbart på en bestræbelse på at blive indordnet. Det påstår jeg, i langt den overvejende grad sker som en fortløbende narrativ indordning mere eller mindre tydeligt allokeret til tilværelsesprojekthistorien om eget liv. Lidt afhængigt af hvilken kognitiv og emotionel stil man som person er præget af, vil det at fortælle sammenhængende være mere eller mindre $i$ forfront (Sternberg 2001). Imidlertid er det uanset stil blevet sværere at finde sammenhæng, fordi kompleksiteten i antal af faktorer og deres indbyrdes relation er steget markant. Det gør det alt andet lige meget sværere at få rum og retning på tilværelsesprojektet.

En naturlig konsekvens af dette faktum er efter min opfattelse, at man naturligvis i et vist omfang må give en 
hånd med tilbud om hjælp til den enkeltes studerendes konstruktion af mulig tilværelsesprojektfortælling, ikke $i$ al almindelighed for alle livets problemer, men for de aspekter, som handler om at finde rum og retning $i$ det karrieremæssige. Når det professionsmæssige, som i HA(psyk.)'s tilfælde også handler om kvalifikationer relateret til processtyring, HR-funktioner af enhver art og psykologisk og erhvervsøkonomisk relateret analyse, og refleksion over virksomheden bliver det centrale, er det naturligvis understreget, at der i et vist omfang skal komme styr på eget tilværelsesprojekt, for at man kan udfolde sig i arbejdsfunktioner.

At arbejde analytisk med eget narrativ $i$ et tidsudspændt forløb over $2 \frac{1}{2}$ år giver med opspænding mod læreproces- og narrativ teori lejlighed til herigennem at konstruere meningen, analysere på den, for igen at forholde sig til den på et meta-niveau $2 \frac{1}{2} 2$ år efter. Denne proces kan kaldes et opgaveorienteret gennemløb af faser i det trefoldige mimesis (Ricæur 2002). Det sker fra 'væren' (præfiguration) over 'fortællingen' med den orden, det giver mulighed for (konfiguration) til så meget overblik, at det skaber overskud af 'nyorientering' og mere målrettet aktivitet (refiguration). Den refleksive forholden sig til eget narrativ under bachelorprojektet giver således mulighed for at gå i metaposition til eget narrativ, ligesom den relative tidsplacering $2 \frac{1}{2} 2$ år efter, giver anledning til synsvinkelforskydningens nye perspektivåbninger. Dette er i praksis at udnytte en social konstrueret erkendelsesproces, hvor proces og erkendelse af proces går hånd $\mathrm{i}$ hånd $\mathrm{og}$ begge robustgør den enkelte studerendes eget tilværelsesprojekt, uden at dette på noget tidspunkt har været udsat for noget, der ligner psykologiserende snagen eller semiterapeutisk aktivitet.

Således fungerer den dobbelte opgave med skrivning og tidsforskudt analyse af eget narrativ både som platform for den studerendes egen kommen til sig selv i professionsudvikling og som platform for erhvervelse af relevante teoretiske rammeforståelser for læring og tilværelsesprojektets placering som rød tråd i livet.

Dertil kommer det andet tema, som kører parallelt med det personlige narrativ, nemlig virksomhedens narrativ. Det giver endnu en mulighed for perspektivforskydning mellem det personlige og virksomhedsmæssige, hvor det relativt hurtigt åbenbarer sig for den studerende, at en virksomheds narrativ på mange måder opbygges efter de samme regler, og indeholder de samme elementer som det personlige.

\section{Gruppedannelsesarbejdet}

I konstruktionen forud for studiets start var der, i arbejdsgruppen som udviklede studiet ikke tvivl om, at mindst halvdelen af eksaminerne skulle tilrettelægges, så de gav mulighed for både at evaluere på faglige faktorer og på samarbejdsmæssige og procesmæssige faktorer. De studerende skal altså arbejde i grupper, og de skal også lære at arbejde sammen med nogen, de ikke selv har valgt. Derfor har vi nu også besluttet at lægge gruppedannelsesproceduren ind i studieordningen som eksplicit og vigtigt. Allerede fra begyndelsen af studiet arbejdes der tydeligt med at give de studerende mulighed for at tilegne sig de styringsredskaber, som kan lette gruppearbejdet (fx procedurer til kontrakttegning, logbogsskrivning, eksplicitering af aftaler og mødestyring (Hermansen, Løw \& Petersen 2004)). Den eksplicitte inddragelse af evaluering af evne til at facilitere en anden gruppes performance er naturligvis også led i dette kvalifikationsarbejde. På et studium, hvor kvalifikationer i vidt omfang handler om at erhverve sig processtyringskompetence, sociale kompetencer til at indgå i samarbejde med alle lag i virksomheden, samtidig med at man erhverver sig de relevante faglige kvalifikationer, må studieordningen og studieprocessen naturligvis afspejle dette, så det også i praksis udkrystalliserer sig. Et studium som HA(psyk.) kan derfor naturligvis ikke afvikles som et individuelt, endsige som et rent teoretisk studium. Selv om vi ikke kan forlange, at de studerende skal møde til undervisningen, må både undervisning og udprøvning forholde sig til den sociale og styringsmæssige side.

I første gennemløb på studiet blev de studerende kastet ud i et lidt barsk gruppedannelsesforløb, som skitseret her:
"Formål:
- At formere funktionsduelige grupper
- Introduktion til Sternbergs teori om laeringsstil
- Øvelse og refleksion over selvdiagnostik
- Øvelse i og refleksion over en socialpsykologisk iscenesat organisationsform til losning af et bestemt problem.
Program:
8.00 Goddag og velkommen. Introduktion til Stern- berg. v/Mads Hermansen.
$8.45 \quad$ Pause
8.55 Selvdiagnostik og selvscoring på Sternbergs ton- kemåde test.
$10.00 \quad$ Pause
$10.10 \quad$ Gruppearbejde 1 i tilfoldige grupper. Opgave at opstille mindst 5 kriterier for gruppedannelse.
11.00 Gruppearbejde 2. Samme gruppe.
11.30 Frokost
12.45 Plenum 1.
Ca. 13.30 Pause
Ca. 13.40 Plenum 2.
Ca.14.20 Gruppearbejde 3.
Ca. 14.40 Pause
Ca. 14.50 Plenum 3.
Ca. 15.30 Evaluering og refleksion.
16.05 Farvel og godt gruppearbejde.

Litteratur: Sternberg, R.J. (2001): Måder at tcenke påtoenkningens stil. Klim.» 
Da de studerende mødte op, fik de ovenstående program, og den første opgave var at udfylde Sternbergs tænkestilstest og at gennemføre en selvscoring. Så fulgte følgende opgave:

\section{" Gruppearbejde 1 i tilfoeldige grupper.}

Opgaven er at opstille mindst 5 kriterier for gruppedannelse. Tag udgangspunkt $i$ larings- og tonkestilstesten. Gruppearbejdet er fordigt, når I har skrevet de fem kriterier på et A4 ark."

Da det var færdigt fulgte:

"Gruppearbejde 2. Samme gruppe. Prioriter kriterierne. Skriv dem på flip-over og hoeng dem op i lokalet."

Så var det tid for:

"Plenum 1. Bliv på hele årgangen enige om, hvilke prioriterede kriterier, der skal laves gruppedannelse efter."

Her fik de endvidere at vide, at de selv skulle styre denne proces, og at de var færdige med arbejdet, når alle på årgangen var blevet enige.

Så fulgte:

"Plenum 2. Fortag en provegruppedannelse efter de opstillede kriterier. Plenum 2 er fordig, når alle har accepteret provegrupperne."

Da alle var placeret i prøvegrupper, fik de følgende opgave:

"Gruppearbejde 3. Forhold jer til sporgsmålet: Hvad ville der ske, hvis provegruppen blev den permanente gruppe for resten af semestret? Provegrupperne drefter resultatet med henblik på en senere dreftelse i plenum."

Efter en tid med drøftelse i prøvegrupperne, blev drøftelsen afsluttet og plenum igen sat.

"Plenum 3. Plenum forholder sig til resultatet. Hvis provegrupperne accepteres som de permanente grupper for resten af 1. semester, er arbejdet fordigt. Hvis der ikke er accept, må der forhandles i plenum til alle accepterer resultatet."

Men hvorfor er det nu nødvendigt med den slags øvelser? Gruppedannelsesprocesser er nogle af de mest vanskelige i næsten alle livets forhold. Hvis man ser ind i den aktuelle politiske diskurs i diskussion om, hvor kvalitetsudviklingen skal ligge i uddannelsessystemet, er der $\mathrm{i}$ hvert fald to tydelige holdninger markeret overfor hinanden. Den ene siger, at senmoderniteten studerende skal have højere faglige kvalifikationer. Derfor må vi tilrettelægge studierne, så det faglige forfølges mest optimalt. I denne diskurs er der en tendens til at nedprioritere de omstændigheder, hvorunder de faglige kvalifikationer er opsamlet og den omstændighed, at faglige kvalifikationer altid mere eller mindre erhverves $i$ sociale eller samarbejdsmæssige sammenhænge. Overfor denne diskurs står den, som jeg er tilhænger af, der hævder, at alle fagligheder altid er nedsænkede $i$ sociale og samarbejdsmæssige processer.Vi kan derfor lige så godt fra begyndelsen arbejde med det relationsorienterede og det sociale. Men netop fordi det er så vigtigt og ofte sårbart, er det nødvendigt at arbejde med det $\mathrm{i}$ små bidder og med en passende progression. Det betyder, at man kan forfølge en målsætning om, at det tilegnes som metode og samtidig bliver bærbart i forhold til den personlige sårbarhed, hvor vi godt ved, at netop den kan være så stor, at man ikke kan lære, fordi man er nødt til at selvbeskytte sig.

Det er som tidligere anført min påstand, at de sårbarhedsprocesser, som eksponeres blandt unge studerende i senmoderniteten, har tendens til at være større end de nogensinde har været for i vores historie. Det handler bl.a. om, at mange af de studerende, vi møder på studierne i dag, er ønskebørn og dermed netop børn som i stort omfang, som unge har været vant til, at der var nogen (forældre især), som ryddede værste forhindringer af banen på børnenes vej. I pædagogkredse kaldes disse børn $\mathrm{fx}$ curlingbørn med en henvisning til sporten curling, hvor det handler om at fă et objekt til at glide så langt hen ad en bane som muligt, bl.a. ved at feje foran det, så modstand og forhindringer ikke sænker farten og mindsker distancen. Hvis senmodernitetens ungdom er præget af et 'curlingsyndrom', eller som jeg siger til min egen søn på 20, et 'fæetterhøjbensyndrom', hvor de umiddelbart tror, at alting lykkes for dem, fordi sådan har det været indtil nu, er det naturligvis endnu sværere at magte de frustrationer, som udspiller sig i gruppedannelser, hvor man både skal forholde sig til egen markedsværdi og ulempen/fordelen ved netop at være samen med specifikke andre studerende. I dette lys bliver to forhold $\mathrm{i}$ hvert fald vigtige: At gå trinvis frem med gruppedannelsesprocessen, så de studerende undervejs i forløbet kan tilegne sig de adækvate kvalifikationer til at magte frustration og sårbarhed, og at arbejde med hvordan man erhverver kvalifikation til at få gruppen til at arbejde, selv om det ikke lige var den gruppe, man helst ville være i.

Men tilbage til gruppeprocessen, der nu principielt var færdig. Så nemt gik det naturligvis ikke, blandt andet fordi jeg ikke havde taget tilstrækkeligt højde for det sårbare, jeg netop har fremhævet. Gruppedannelsesprocesser er meget sårbare, hvor der også er tendens til, at de mest sårbare også bliver de mest udstillede. Der kan være mange former for sårbarheder $i$ spil, og konceptet, som det er formuleret her, søger i virkeligheden at mindske sårbarheden mere end det traditionelt sker, hvor processen ligner markedets med til- og fravalg. Konceptet gør det ved at udskyde den endelige gruppedannelse med det indskudte 'legende' led, som handler om 'prøvegrupper'.

Forløbet blev altså ikke helt afviklet, som det var intentionen, idet der på dette første forløb på et helt nyt studium var endnu større sårbarhed blandt de studerende, end jeg havde forestillet mig, og det er måske yderligere en understregning af, hvor sårbart det er med gruppedannelsesprocesser. I den proces, hvor jeg forsøgte at give mulighed for at oparbejde kvalifikationer undervejs i en konkret gruppedannelsesproces, blev jeg alligevel overhalet af det faktum, at selv med en tidsudskydelse og iscenesat refleksionsproces blev 
det for hårdt for nogle af deltagerne. Jeg var derfor som overordnet procesleder nødt til at improvisere hen over forløbet. Fx da den kendte socialpsykologiske effekt viste sig under gruppearbejde 3 og plenum 3, hvor dem, der nu syntes, at de sad i de grupper, som i den grad var dem, de gerne ville være i, mentalt krydsede armene over brystet og ventede på at dem, der endnu ikke havde fundet en prøvegruppe at være i, blev færdige med arbejdet. Det vil sige, at denne proces trods intentioner og planlægning, tendentielt blev lige så sårbar som et egentligt marked.

En af mine improvisationer bestod bl.a. i at stoppe processen for at spørge om nogle af de grupper, som syntes, at de som prøvegruppe var på plads og i orden, kunne overveje at invitere nogle af løsgængerne ind, idet jeg samtidig understregede, at vi ikke kunne komme videre, før alle var med i en prøvegruppe. Det gav anledning til noget opbrud og forhandlinger. Imidlertid stod vi selv efter denne runde stadig med nogle, som ikke var blevet knyttet til prøvegrupper. Først da jeg stoppede processen og foreslog, at vi i stedet formerede grupper ved hjælp af simpel tælling til 12 (det ville give 12 grupper a 6 personer), kom prøvegrupperne på plads. Derefter kunne vi gå til undersøgelsen af, om prøvegrupperne nu kunne bruges som arbejdsgrupper hen over semestret. Det kunne de, viste det sig i løbet af ganske kort tid.

\section{Evaluering af gruppedannelsesprocessen}

Naturligvis måtte denne proces evalueres. Det gjorde jeg ved at invitere alle studerende til et evaluerende møde med følgende invitation:

"Kare alle

Så kom vi igennem en lang, måske larerig, men også lidt sårbar proces, som endte i en gruppedannelse.

Formålet med dagen var:

- At formere funktionsduelige grupper

- Introduktion til Sternbergs teori om laringsstil

- Øvelse og refleksion over selvdiagnostik

- Øvelse i og refleksion over en socialpsykologisk iscenesat organisationsform til losning af et bestemt problem.

De fire formål forfulgte vi hen over dagen, og jeg synes, der var meget engagement og medliv i gruppens måde at forholde sig til de konkrete faser i forlobet. På den måde fik jeg bekraftet min opfattelse af holdet, fra de forste gange vi var sammen, som et energisk hold med masser af initiativ og mod på det studium, vi nu har taget hul på. Denne opfattelse er blevet styrket, og jeg synes på mange måder, at vi fik et fint forlob, men når der arbejdes praktisk og iscer i psykologiske registre, er det naturligvis lettere at lobe ind $i$ knubs både som studerende og laerere. Det er en del af kvaliteten, men naturligvis også noget som hele tiden skal justeres, så de knubs man fär, bliver grundlag for laering og udvikling. Hvordan fordelingen var $i$ går mellem det produktive og måske for sårbart udleverende, er naturligvis meget afhoengig af, hvorfra man ser, men her fär I min version.
Jeg inviterer til et supplerende evaluerende og reflekterende mode på torsdag $d .9$ sidst på eftermiddagen.

Men altså min oplevelse af $i$ går:

At teste sig selv og herudfra tage anledning til at overveje de aspekter som testen highlighter, er en god anledning til at forholde sig undersegende og mulighedsåbnende overfor, hvordan man oplever egne styrker, og hvad det er man skal passe på. Forudscetningen er, at man går med på promisserne og faktisk ser testningen som en mulighed for selvrefleksion. Min oplevelse var, at sådan blev selvtestningen også brugt. Selvdiagnosticeringen skulle bruges $i$ forhold til opstilling af kriterier for gruppedannelse. Her opstod der tvivl, og kriteriedannelsen blev ikke det gode instrument, det kunne have veret for at formere gode arbejdsgrupper. Som jeg citerede Wilfred Bion for, så er en arbejdsgruppe karakteriseret ved, at den er orienteret mod at lose en bestemt arbejdsopgave, og at den er äben. Det betyder, at opgaven er i centrum. Gruppens afgreensning og selvopretholdelse må ikke blive formål $i$ sig selv, for hvis det sker, så er det gruppens overlevelse, det handler om. Gruppen er så allerede ved at blive en 'patologisk gruppe', som forfolger sin egen overlevelse og ikke losning af en opgave.

Da dagen spidsede til, og gruppedannelsen var så langt fremme, at nogle havde etableret sig trygt $i$ de mulige grupper, var det min oplevelse, at nogle grupper allerede havde lukket sig.

Men kriterierne blev ikke fardigudviklede, og diskussionen blev lukket med en konstatering af, at det var man, da jeg spurgte. Det kan jeg godt forstå, for utålmodigheden voksede og flowet, som det blev sagt, gik $i$ stå. Men det er lige netop her, at det processtyringsmaessige bliver vigtigt. Det fik vi toenkt hojt med hinanden om, og selv om der blev kampet bravt fra de to 'ordstyrere', (to studerende havde meldt sig som ordstyrere) var frustrationsniveauet blevet så hojt, at der måtte ske noget, og det blev så erklaringen om, at nu var opgaven lost. Det, der skete her, er efter min opfattelse godt at tage ved laere af. Beslutninger, som tages fordi der er tidspres, stress og utålmodighed, er ofte ikke sarligt kvalificerede. Utälmodighedsgrenserne er meget forkellige hos mennesker, måske meget forbundet med hvilken tenkestil man er domineret af, men også forbundet til andre forhold.

Jeg er som underviser altid glad, nar der er initiativ og engagement hos mine studerende. Jeg synes jeres hold er praget af mange, som gerne vil tage initiativ, og der blev virkelig kampet med problemer, som er svore at processtyre. Min oplevelse var, at det kom der gode refleksioner ud af, da vi i fellesskab så på, hvad der var sket. Jeg tror det havde voret godt, om vi her havde dvalet lidt mere ved oplevelser og erkendelser af, hvordan man kunne have gjort noget andet. Men vi moerkede helt ind $i$ vores krop ustyrligheden, og også at det ustyrlige under bestemte rammebetingelser er mere styrligt. Det er en vigtig pointe, for det er det, vores uddannelse også handler om.

Kriteriedannelsen kunne således have veret mere klart formuleret som opgave fra min side. Jeg tror, det ville have veret hjoclpsomt, om det havde veret et krav, at kriterierne skulle have veret så specifikke, at det kunne afgores, om 
man levede op til dem. Mand/kvinde er eksempel på et sådant et kriterium, men det er forskellige stil/ens stil også. Den sorte hest $i$ alle gruppedannelsesprocesser er imidlertid forholdet mellem det, man kunne kalde karlighedsprincippet og arbejdsprincippet, hvor det forste handler om dem, man gerne vil vare sammen med, fordi man kan lide dem, og det andet handler om at gå efter maksimering af gruppens arbejde med opgaven. Karlighedsprincippet bruger vi $i$ venskab og karlighed, men vi synes det er svart hyggeligt, hvis det også kunne galde $i$ arbejdsliv og fritidsliv. Selv om netop karlighedsprincippet tenderer mod at gøre arbejdsgruppen patologisk og ikke arbejdsorienteret, er det en naturlig forste reaktion, som kan blive uhensigtsmassig for opgavens losning. I arbejdsgruppedannelser korer der derfor altid en lang rakke dagsordener, hvoraf nogle ikke diskuteres. Det gjorde der også $i$ går. Jeg tror vi fik illustreret mange af dem, men jeg tror at det havde varet godt, om jeg havde vagtet det arbejdsgruppeorienterede mere fra begyndelsen. Grupperne skal vare arbejdsgrupper. Vi fik $i$ hvert fald mod slutningen af dagen $i$ den grad illustreret det fonomen, at dem der har deres på det torre, med korslagte arme venter på, at dem, der stadig har et problem, far lost det. Abninger var der imidlertid flere, som konstruktivt bød ind med, men hvis vi ser på villigheden til at gore det, blev det forst rigtig alvor, da jeg sagde, at nu gik vi i praksis over til at lave grupper ved nummeropräbning.

I min tilrettelagggelse af dagen var vagten mellem det at illustrere de sociale processer, og det at komme knubset, men helskindet igennem processen, ikke optimal. Jeg beklager og undskylder, hvis nogen har folt sig svigtet. Jeg håber imidlertid, at dagens processer kan danne grundlag for analyse, refleksion og deltagelse $i$ det falles arbejde med at skabe de processtyringskompetencer, der skal til for at lette flowet $i$ den sociale proces, så det bliver både arbejdsorienteret, men også hyggeligt.

Med venlig hilsen

Mads«

Så med gamle Gotha Andersens overlærer, der i mine yngste børns ungdom i TVs ungdomsuddannelser spurgte ud i blandt seerne, kan jeg nu spørge: Og hvad kan vi så lære af det? En del af svaret er givet i ekskursen ovenfor. En god del af resten af det ligger naturligvis i det faktum, at undervisning, og især undervisning som beskæftiger sig med vanskelige og sårbare processer, altid konkret må evalueres og diskuteres i lyset af det skete, og den teoretiske diskurs man nu læner sig op af. Som de senere overvejelser vil åbenbare, medførte processen naturligvis også i dette tilfælde sådanne justeringer.

Brevet blev fulgt op med invitation til evalueringsmødet, hvor vi hen over en række refleksive spørgsmål, som skulle drøftes i grupper, kunne forholde os til processen. Det blev formuleret som følgende oplæg:

\section{"Evaluering af gruppedannelsesarbejde}

Formål:

Vi skal nu og den kommende time til halvanden prove at forholde os evaluerende til Gruppedannelsesprocessen. For at denne aktivitet skal få både så godt et resultat som muligt og vare lacerigt på, hvordan man styrer processer (her evaluering), har jeg folgende forslag til procedure:

Grundloggende arbejder vi med evalueringen $i$ studiegrupper afbrudt af plenumrunder.

Procedure i studiegrupper:

- Voelg en referent, der skriver stikord fra runden.

- Gruppen starter en runde med sporgsmål 1. Den forste siger 1-2 scetninger, sà folger noeste osv.

- Efter runden konfererer referenten med de ovrige, om hvad der skal siges i plenum.

Procedure i plenum:

- Referenterne refererer i tur fra gruppernes droftelse.

- Mads' betragtninger hores ligeledes i hver plenumrunde.

- Derefter korte supplerende synspunkter fra ovrige deltagere.

Når alle tre runder er gennemarbejdet, vil der blive en kort plenumrunde med supplerende betragtninger. Mads styrer plenum og tiden.

1. Hvilke positive forhold har jeg hoeftet mig ved i gruppedannelsesprocessen?

2a. Hvad er jeg evt. glad for at jeg selv gjorde?

2b. Hvad undlod jeg at gøre, som evt. kunne have påvirket processen konstruktivt?

3a. Hvad har jeg iscer loert at vare opmorksom på som deltager i gruppedannelsesprocesser?

3b. Og hvad har jeg iscer laert om proceslederens opgaver?"

\section{Udmeldelse af eller udsmidning fra grupper}

Ved begyndelsen af 2 . semester, hvor vi igen lavede en gruppedannelse, som jeg ikke vil komme nærmere ind på her, lavede jeg et oplæg til præcisering af forhold omkring udtræden af grupper. Her brugte jeg erfaringen med, at der ved gruppedannelser altid findes lokale utilfredsheder og ønske om at få lov til at melde sig ud eller smide nogen ud eller skifte gruppe. En eksplicitering af disse forhold måtte altså være på sin plads. Jeg skrev:

"Kare Studerende på $H A(p s y k$.

Oplag til procedure for udtrcedelse af gruppe, gruppeoplosning og udelukkelse af medlemmer.

Det har berettiget fra nogle af jer varet fremhovet, at gruppedannelsesprocesserne ikke, som jeg har hovdet, helt lignede det, der sker $i$ det private erhvervsliv. Her er det jo netop muligt for en virksomhed at fyre den medarbejder, som ikke på ordentlig vis kan indgå $i$ arbejdet og den sociale kontekst. Også $i$ den private sfare kan man jo fyre og blive fyret, det sker, der hvor man lader sig skille fra karester og agtefolk, hvis kontrakten ikke overholdes. Derfor kan vi naturligvis ikke på $H A$ (psyk.) have vores egne regler, som gor det umuligt at komme ud af en gruppesammenhang, hvor kontrakten ikke overholdes. Når store dele af studiet således skal afvikles $i$ grupper, skal vi naturligvis ud over regler for gruppedannelse også have regler for, hvordan grupper opløses, og for hvordan man kan komme ud af grupper, eller hvordan man kan 'fyre' 
et gruppemedlem. Dette papir er oplag til begyndelse på en sådan regelsatning.

Noglebegrebet $i$ dette arbejde må efter min opfattelse vare 'Kontrakten'. Enhver gruppedannelse må derfor indeholde en diskussion af, hvordan kontrakten skal udformes. Enhver begyndelse på gruppens arbejde må indeholde en fase, hvor man aftaler hvilken kontrakt, man arbejder efter. Hvis kontrakten er udformet ordentligt, vil det vare tydeligt for deltagerne, når den bliver brudt, og man derfor kan påbegynde den proces, som kan lede til udelukkelse af medlemmer eller oplosning af gruppen.

I erhvervslivet har man et meget fintmasket regelsat, der gør, at den enkelte medarbejder $i$ virksomheden er sikret mod tilfaldigheder i fyringssager. Disse regler er indskrevet $i$ overenskomster og lovgivning. Her på HA(psyk.) skal vi naturligvis have gode regler, som både beskytter den enkelte, og som giver god grund for ordentlig udmeldelse af grupper eller oplosning af dem. Hverken her på HA(psyk.) eller i erhvervslivet bruger man anarki eller 'karlighedsprincippet', når man skal satte medarbejdere $i$ arbejdsgrupper. Der skal regler og kontrakter til. Det forste I således kan drøfte i jeres undersøgelse i gruppen $i$ dag, er de regler I vil arbejde efter, hvis I voelger at gøre denne gruppe til arbejdsgruppen hen over hele semestret.

Den gruppe I $i$ dag kommer $i$, er den gruppe I principielt går til eksamen $i$, med mindre den oploses efter de regler, som I selv formulerer, og at det bliver accepteret $i$ studieadministrationen.

Pinde til kontrakt. Klare aftaler om:

- Arbejdsindsats. Skal alle yde nogenlunde samme indsats?

- Arbejdsdeling. Kan eventuelt tage udgangspunkt $i$ toenkestil eller Belbinkategori.

- Mødefrekvens. Kommentar: Hvor tit, hvor og hvor lange modes man?

- Modedisciplin. Regler for forberedthed, at komme til tiden, melde afbud, vare aktiv og medkonstruerende, etc.

- Modestyring. Laver man fast dagsorden? Er der rollefordeling på fx modeledelse og procesledelse? Tager man 'small talk' forst på dagsordenen eller sidst på mødet? Etc. Kommentar: Brug gruppen til det, den er god til, og lad vare med at lave langere moder end der er grund til (stå eventuelt op under moderne, møder som er langere, end man kan holde ud at stå op, er for lange).

- Oplag til arbejdet, når man mødes. Kommentar: Møder er gode til diskussion, brainstorm, kritik, mulighedsåbninger, aftaler, etc., men de er jount hen dårlige til at lave konkret arbejde som loesning af tekster, arbejde med formulering af tekster etc. Disse aktiviteter foregair bedst i enrum foran computeren.

- Definition på brud på de regler I har lavet, er hjoelpsomme. Lav dem så eksplicitte, at de kan kommunikeres til andre, så de kan forstå dem. Kommentar: Det skal vare tydeligt at man har forbrudt sig mod gruppens kontrakt. En granse kan $f x$ vere: Har to gange ikke lavet lovet oplag. Eller: Kommet for sent til gruppens mode to gange uden at meddele det til de andre. Etc.

- Evaluering. Hvad skal evalueres, hvornår og hvordan?
Hvis gruppen har lavet en kontrakt om arbejde og arbejdsform og gruppemedlemmer har forbrudt sig mod dem, kan det medfore at vedkommende 'fyres' fra gruppen. Grunden til en fyring eller en oplosning af en gruppe skal sandsynliggøres for den semesteransvarlige, studielederen eller studieadministrationen. Retten til at forelogge en 'fyringssag', en gruppeoplosning eller et onske om udtrceden af gruppen forudscetter, at gruppen har lavet en kontrakt, og at kontrakten er overtrådt. Når det er sket, er det studieadministration, der sammen med den eller de enkelte studerende udformer regler for det videre arbejde alene eller i gruppe. Dispensation fra kravet om gruppeeksamen kan kun gives af studienovnet.

Til velvillig viderekonstruktion.

Fra Kommunikation og samarbejde (Hermansen, M. m.fl. 2004) kan man endvidere fä inspiration på side:

209, Spilleregler og teambuilding

210, Teambuilding

216, Evaluering og samarbejde

217, Lynevaluering af mødet

184, Procesledelse og konflikthaindtering.

Mads«

Naturligvis løste dette ikke alle problemer. Uanset hvor tæt man laver ét regelsæt for noget så ømfindtligt som gruppedannelser, vil der være tabere og vindere i spillet. At hævde, at man i undervisning bare nogenlunde matchende kan mime det sociale spil i virksomheden, vil naturligvis være urimeligt. Ikke desto mindre er aktiv mimen, netop et af målene med den måde vi konceptualiserer uddannelse på. Ud over rimelige procedurer for opløsning af gruppen måtte vi naturligvis fortsat i studienævnet arbejde med en yderligere raffinering af denne efterligning. Det tog jeg initiativ til ved en drøftelse i studienævnet med udgangspunkt i et oplæg, som jeg havde lavet om gruppedannelsesprocessens taksonomiske progression. Dette oplæg dannede udgangspunkt for, at jeg $\mathrm{i}$ en mindre arbejdsgruppe sammen med to studerende justerede en procedure, hvor formålet aktivt var at efterligne virkeligheden fra erhvervslivet. Vi søgte at eksponere det forhold, at man i vidt omfang som ansat er underlagt en form for overbestemmelse fra ledere eller faglige matchende formål, som gør, at man er nødt til at arbejde sammen med mennesker, som man enten ikke kan lide, ikke arbejder godt sammen med, synes er underydere eller lignende. Karakteristisk er det vel, kan man hævde, at det først hen over et længere arbejdsliv er muligt for en at få større og større indflydelse på, hvem man skal arbejde sammen med.

En realistisk mimen hen over de tre studieår måtte derfor gå fra næsten ingen indflydelse til større og større indflydelse på arbejdsgruppedannelsesprocessen. Forslaget kom i sin foreløbigt endelige udformning til at se således ud og indgår nu som tekst i den studieordning, som gælder for årgang 2005: 


\section{Gruppedannelsesprocedure på $\mathbf{H} A(p s y k$.}

$H A(p s y k$.) er et studium, hvis formål strakker sig over kompetenceerhvervelse $i$ forhold til personlige, sociale, tvarfaglige, faglige og til det performancemassige. Som konsekvens af dette foregair store dele af studiet i gruppe, ligesom store dele af eksamensaktiviteterne gor det. Dette forhold satter naturligvis gruppedannelsesprocesserne $i$ centrum $i$ studiet. Både $i$ uddannelse, og senere erhvervskarriere vil man i nogle sammenhonge blive sat i grupper med nogle, man ikke selv har haft indflydelse på, blev del af gruppen. Det betyder, at man $i$ et vist omfang er nodt til at erhverve kvalifikationer til arbejde sammen med nogle man ikke sympatiserer med, eller ikke har samme stil med etc. At erhverve de sociale og samarbejdsmassige kompetencer der handler om samarbejde på tveers af sympati og stil, er således en del af de kvalifikationer, der skal oparbejdes.

I lyset af dette kunne man hen over studiet opbygge gruppedannelsesprocesserne taksonomisk fra nosten ingen indflydelse på gruppevalg $i$ begyndelsen over mere og mere indflydelse, for til sidst at ende med frit valg $i$ slutningen af forlobet.

Gruppedannelsesprocessen forlober efter folgende form:

- Ved begyndelsen af 1. semester udfylder de studerende elektronisk R. Sternbergs tenkestilstest. På grundlag af på forhånd opstillede kriterier for gruppedannelse (grupper på 6) dannes grupperne. Kriterierne udformes af den fagansvarlige for 1. semester og godkendes $i$ studiencevnet.

$\checkmark$ Gruppedannelsen foregår ved, at computeren udvelger de enkelte grupper efter de opstillede kriterier.

$\checkmark$ Gruppens forste opgave er efter dannelse er at udforme en kontrakt om arbejdsform, tidsforbrug, forberedthed etc. Denne del af arbejdet foregår efter en plan, hvor der arbejdes igennem folgende faser: 1) De dannede grupper drefter hvilke kriterier, der skal indgå $i$ en samarbejdskontrakt for arbejdet. 2) Grupperne prioriterer de fem vigtigste kriterier og skriver dem på et flip-overark, som slås op i undervisningslokalet. 3) Der veclges en procesleder blandt de studerende, som nu sekunderet af underviseren forestår en forhandling af og beslutning om hvilke kriterier, der skal gaelde for gruppernes samarbejde i semestret.

$\checkmark$ Grupper kan i lobet af semestret kun oploses eller udelukke medlemmer, hvis det kan sandsynliggores, at der er sket brud på den opstillede kontrakt. De fagligansvarlige laerere er forste instans $i$ en sådan gruppeoplosningsprocedure.

- Ved begyndelsen af 2. semester udfylder den enkelte studerende elektronisk en Belbin grupperolletest.

$\checkmark$ Der vil efterfolgende blive holdt et seminar, hvor de studerende arbejder i en proces i grupper og i plenum. Opgaven er at blive enige om, hvordan grupper skal scettes sammen. Det grundlag, som beslutningen skal foregå på, er alene de ansigtslose profiler over de enkelte studerende. Kriterierne er, at hver gruppe skal indeholde en tydelig igangscetter, en tydelig fardiggører og en tydelig administrator. Først når alle pro- filer er placeret $i$ grupper, sattes profiler og personer sammen.

$\checkmark$ Samme producere som på 1. semester med kontrakt og procedure for oplosning eller udmeldelse.

- Ingen gruppedannelse på 3. semester. Eksamen er individuel. Eventuelle losegrupper organiseres af de studerende selv.

- Ved begyndelsen af 4. semester samles de studerende til et endagsseminar, hvor der er folgende trin i gruppedannelsesprocessen: 1) I tilfaeldige grupper på 5 diskuteres og prioriteres tre kriterier for gruppedannelse. Kriterierne skrives på flip-overark og sattes op på vaggen. 2) De studerende volger en iblandt sig til at lede gennemforelsen af en falles prioritering af kriterier. Denne fase er fordig, när der enighed om en folles prioriteret liste. 3) Der laves et marked, hvor de studerende far lejlighed til at undersege, hvordan grupperne kunne komme til at se ud (grupper på 3). Dette arbejde er fordigt, hvis der er tilslutning fra alle til, at denne proces nu er slut. 4) Hvis der ikke kan blive enighed, har vi to muligheder: At blive ved til processen er afsluttet eller ved at foretage en lodtrekning.

$\checkmark$ Samme procedure som på 1. semester vedrorende gruppeoplosning og -udmeldelse.

- Ved begyndelsen af 5. semester fär de studerende lejlighed til at danne grupper (3) uden kriterier og uden indblanding fra undervisere.

$\checkmark$ Grupperne meddeles til studiesekretceren, senest inden udgange af den uge, hvor semestrets undervisning er sat $i$ gang.

- Ved begyndelsen af 6.semester vil der ikke vare nogen gruppedannelsesproces, men senest d. 1. november skal der foreligge et bud på, hvem der skal vere opponent ved en bachelorprojekteksamination. Og man er opponent for hinanden. Man finder selv sin opponent.

En længere teoretisk argumentation omkring kontrakt og de socialiserende aspekter ved gruppedannelsesprocessen kunne i sig selv fylde bøger. Alene af pladsmæssige grunde bliver det derfor for omfattende at gå ned $i$ en grundig teoretisk udredning. En antydning skal dog anføres.

Et centralt begreb er 'social kapital', som Bourdieu (1979) definerer det. Begrebet parafraserer især 'økonomisk kapital' og specielt i Bourdieus præciseringer bliver det tydeligt kædet sammen med magt og indflydelse. I min bestemmelse af social kapital kan det beskrives således: Social kapital er den fond af socialt betingede trækningsrettigheder eller sociale ressourcer den enkelte person har i forhold til de formelle og uformelle netværk den enkelte indgår i, og som potentielt eller reelt kan konverteres til indflydelse. At besidde social kapital er således sammenhængende med et bredt spektrum af vilkår for den enkeltes liv: hvilke forældre man fik, hvilken skole man gik i, personlighedsfaktorer, grad af empatisk spejlende voksne i skole- og institutionsliv etc. Det er således oplagt, at de enkelte studerende, når de begynder på studiet, har mere eller mindre social kapital med, og at nogle i den 
udveksling af kapitaler, som naturligvis starter lige fra første minut af introforløbet qua deres udgangskapital, vil være $i$ en bedre position til at lægge kapitalen til formuen $\mathrm{fx}$ i form af hurtigt oparbejdet større symbolsk kapital.

Et af de skift $i$ vilkår for erhvervelse af social og symbolsk kapital, som markant er sket hen over i hvert fald de sidste 40 år, handler om, at mere og mere af den sociale kapitalerhvervelse er relateret til det at have eller få arbejde, hvor det tidligere også var tæt funderet i nabo- eller kvartersvilkår og i foreningsliv. Specielt er det tydeligt, at det netværk som var i kvarteret eller i karreen ikke i samme grad findes mere, al den stund de hjemmearbejdende kvinder udgjorde en stor basis i dette netværk, og de er i hvert fald i dansk sammenhæng netop på arbejdsmarkedet. Det er altså min påstand, at muligheden for at erhverve social kapital øges med muligheden for at være i relevante netværk. Og her er vi i vidt omfang udleveret til arbejdet som grundlag.

Uddannelse er endvidere mulig indgangsbillet til arbejdsmarkedet. På den måde er stor uddannelseskapital et kapitalgode, som lader sig konvertere til social kapital, fordi det øger muligheden for at få privilegerende adgang til attraktive netværk. Konsekvensen af dette er imidlertid også, at arbejdet på den måde ikke alene er betydningsfuldt for opretholdes af et livsgrundlag, men også bliver en vigtig faktor for at kunne fă del i den symbolske udveksling omkring erhvervelse af social kapital.

I slipvinden af denne påstand ligger naturligvis den konsekvens, at de nye klassedelingslinjer netop går imellem dem, der via arbejde har adgang til netværk og dermed til fortsat udveksling og akkumulation i det sociale kapitalfelt, og dem der ikke har. Man kan være skræmt af denne udvikling eller bare tage den som et vilkår, men under alle omstændigheder er det noget man skal orientere sig efter, og noget som har stor indflydelse på, hvilke linjer ens liv kan komme til at udvikle sig langs. Hvis større klassedeling og dermed potentielt større samfundsmæssig ulighed er konsekvensen, bliver kampen om det marked, hvor udvekslingen af social kapital kan udfolde sig, også større. Det er min opfattelse, at vilkåret er ret skræmmende, men at der ikke er noget alternativ til aktørmæssighed i forhold til det. Det handler derfor naturligvis om at erhverve så mange sociale kvalifikationer som muligt, men det handler naturligvis også om at erhverve de sammenhængsskabende dele af den sociale kapital, der gør at man undersøgende og mulighedsåbnende kan få situationer, hvor der er stor social kapitalulighed til at fungere.

Specielt hvis man sigter på et arbejdsfelt med styring og ledelse af sociale processer (som HA(psyk.) bl.a. også gør) er det vigtigt at kunne magte dette. På den måde får tilrettelæggelsen af de sociale processer på studiet en dobbelt funktion: At erhverve de selv- og andenstyringskvalifikationer der gør, at man i prak- sis kan arbejde sammen med dem man skal arbejde sammen med, at man kan reflektere sammenhæng og nødvendighed, og at man kan holde det ud.

\section{Diskussion Gruppedannelsesarbejdet}

Menneskets hele kommen til sig selv er socialt (Kohut 1990, Mead 1934, m.fl.), ligesom det er kulturelt situeret og betinget af en genfortolkning af de kulturskabte artefakter og værker (Ricæur 2002), selv om en aktuel samtid vægter det individuelle og det personlige og ofte næsten ad absurdum, som det fx sker i øjeblikket, hvor det fagfaglige gøres til den væsentlige parameter. Det sker fx i aktuelle gymnasie- og folkeskolereformer. Aktuelt forholder rapporten: Humanistiske kandidater og arbejdsmarkedet (Videnskabsministeriet 2005) sig til denne problematik. Fx fremhæver formanden for udvalget: "Universitetsuddannelsen bliver for denne humaniorastuderende ikke bare et dannelsesprojekt. Men et personligt udviklingsprojekt, hvor man ikke kan tage hensyn til småligheder som institutionelle rammer og solidaritet med andre studerende. Det kan ifolge Hesseldahl risikere at diskvalificere den humanistiske studerende fra forpligtende fallesskaber" (Information 4/3-05, p. 30).

Det er altså indlysende, at en af de kvalifikationer, som nødvendigvis må oparbejdes både i forhold til erhvervskarriere og videre studium, er evnen til at indgå produktivt i samarbejdssituationer og i fællesskaber. Netop vægten i samtiden på det individuelle valg og kravet om at oparbejde personlige kompetencer, kan for nogen give anledning til at undervurdere de sociale kompetencer (Person 2002).

Man kan sige, at den måde vi arbejder på, kalder på en professionalisering af de personlige og sociale kompetencer, således at de studerende bliver i stand til handle, analysere og konfliktløse de uoverensstemmelser, der naturligvis altid opstår i samarbejder. Samtidig med at der arbejdes praktisk med gruppedannelsesprocesser, benyttes lejligheden naturligvis også til at lægge et teoretisk spor ud, som indeholder relevante fragmenter fra social- og personlighedspsykologi. Således illustrerer arbejdet med gruppedannelser også den induktive vinkel.

Alle gruppedannelser evalueres, og det sker i regi af systemisk inspirerede spørgsmål, som kalder både på en vurdering (tilfredshed, udbytte) og på en evaluering af egen indsats (Hermansen, Løw \& Petersen 2004).

\section{Konklusion}

Jeg har ved eksempler fra studieplan og oplæg til studieaktiviteter i to spor - et narrativt og et socialt - antydet, hvordan den pædagogiske og uddannelsesmæssige tænkning har udkrystalliseret sig på et universitetsstudium.

I påstand synes jeg således, at jeg har illustreret, at HA(psyk.) er et godt svar på krav til en uddannelse i senmoderniteten. Det er den fordi: 
- Den tager udgangspunkt i handling som teoretiseres (mimesis)

- Den giver de færdige bachelorer konkrete og brugbare kvalifikationer til at indgå i erhvervsmæssige virksomheder eller fortsatte akademiske studier

- Den tilnærmer den akademiske bachelor til den opfattelse, som præger den angelsaksiske tradition og ideologisk præger professionsbacheloruddannelserne i Danmark

- Den yder funktionel støtte til de enkelte studerendes projekt med at komme til sans og samling $i$ forhold til eget tilværelsesprojekt for så vidt angår det karrieremæssige

- Det hjælper dermed også den enkelte studerende i konstruktion af sig selv som aktiv studerende, der selv i samarbejde med andre studerende og undervisere skaber de muligheder, som realiserer sig $\mathrm{i}$ relevante kompetencer.

\section{Litteratur}

Bertelsen, P. (1994). For evigt forbundet. De almenpsykologiske potentialer i Kohuts selvpsykologi. Psyke og Logos nr. 2 p. 267-316.

Bion, W. (1961). Experiences in groups - an other papers. London. Tavistock.

Bourdieu, P. (1979). Distinction: a social Critique of the Judgement of Taste. Cambridge. Routledge \& Keagan Ltd.

Bruner, J. (1999). Uddannelseskulturen. Socialpædagogisk Bibliotek.

Gergen, K. G. (1997). Virkelighed og relationer. Dansk Psykologisk Forlag.

Hermansen, M.(1999). Skolens fortælling om sig selv - en narrativ vinkling. I: M. Hermansen (red.), Kvalitet i skolen - praksis. Klim.

Hermansen, M. (2001). Den fortallende skole - om muligheder i skoleudviklingen. Klim.

Hermansen, M. (2002a). Historiefortælling som vejen til læringen. Hjemkundskab nr. 5.

Hermansen, M. (2002b). Læring og undervisning I: S.E. Holgersen og F.V. Nielsen (red.), Musikalsk læring. Konferencerapport. Danmarks Pædagogiske Universitet.

Hermansen, M. (2002c). Skolens fortælling - skolens udvikling. Kognition \& Pedagogik nr. 44.

Hermansen, M. (2002d). Udvikling og læring - og et standpunkt. I: M. Hermansen \& A. Poulsen (red.), Samfundets born. Århus. Klim og Pædagogisk Bogklub.

Hermansen, M. (2003a). De studerende skal blive voksne. Ernoringsog husholdningsøkonomen. Nr. 11/12.

Hermansen, M. (2003b). Den gode kommunikation og samarbejde. Ernarings- og husholdningsekonomen. 4/.

Hermansen, M. (2003c). Hvad er pædagogisk psykologi? Psykologisk Pcedagogisk Rådgivning. Nr. . 6.

Hermansen, M. (2003d). Indledning. I: A. Persson, Social kompetence - når individet, de andre og samfundet mødes. Klim.

Hermansen, M. (2003e). Lærerarbejdet i forandring. Ernarings- og husholdningsøkonomen $\mathrm{nr} .1$
Hermansen, M. (2003f). Læring og undervisning i professionsuddannelse. Uddannelsesnyt nr. 4.14 årg. p. 11-18.

Hermansen, M. (2003g). Omlaring. Klim.

Hermansen, M. (2003h). Udviklingsarbejdets muligheder og vildveje. I: B. Ryberg \& M. Thrane (red.), Skolen som laerende organisation - $i$ teori og praksis. Klim.

Hermansen, M. (2004a). En konstruktivistisk vinkel på undervisning. I: M. Hermansen \& E. Jensen (red.), Udfordringer til undervisningen $i$ didaktisk perspektiv. Alinea.

Hermansen, M. (2004b). Genopliv historiefortællingen. Kraka nr. 27. 7. årg.

Hermansen, M. (2005). Læring. I: H. Cornelius og K. Schnack (red.):Voksenpadagogisk opslagsbog. Christians Ejlers forlag.

Hermansen, M. \& Herløv Petersen, M. (2003). Introduktion: At lede pædagogiske processer er ikke management. I: M. Herløv Petersen \& M. Hermansen (red.). Ledelse af skoler og padagogiske institutioner - er det management? Klim og Gyldendals Akademiske Bogklubber.

Hermansen, M. \& Jensen, M. E. (2004). Didaktik i en opbrudstid. I: M. Hermansen \& E. Jensen (red.). Udfordringer til undervisningen $i$ didaktisk perspektiv. Alinea.

Hermansen, M., Løw, O. \& Petersen, V. (2004). Kommunikation og samarbejde $-i$ professionelle relationer. Alinea.

Hermansen, M. \& Petersen, V. (2002). Lærerværelsets fortællinger. Skolen i Morgen nr. 7.

Illeris, K. (2000). Adult education in the Perspective of the Learners. Roskilde Universitetsforlag.

Information (2005). Universitetsuddannelsen. Information 4/3, p. 30.

Kohut, H. (1990). Selvets psykologi. Reitzel

Kristensen, H. J. (1991). Peedagogisk teori i praksis. Gyldendal.

Mead, G.H. (1934). Mind, Self and Society from the Standpoint of a Social Behaviorist. Chicago University Press.

Nielsen, V. O. (1976). Problemorientering og funktionel tværfaglighed. DPT nr. 8.

Person, A. (2002). Social kompetence. Klim.

Ricæur, P. (2002). En hermeneutisk brobygger. I: M. Hermansen \& J. D. Rendtorff (red.), Tekster af Paul Riccur. Klim.

Simonsen, B. (1998). Individualisering og demokrati i ungdomsuddannelserne - tekster om 'De nye unge - de nye voksne' I: K. Illeris m.fl., Udspil om laring og didaktik. Roskilde Universitetsforlag.

Simonsen, B.(1999). 90'ernes krævende unge - og nogle mulige pædagogiske konsekvenser. I: T. Størner \& J. A Hansen (red.), Ungdom - uddannelse og kultur. Danmarks erhvervspædagogiske uddannelse.

Sternberg, R.J. (2001). Måder at toenke på - tonkningens stil. Klim.

Videnskabsministeriet (2005). Humanistiske kandidater og arbejdsmarkedet. København.

Ziehe, T. \& Stubenrauch, H. (1983). Ny ungdom og udscedvanlige lareprocesser - Kulturel frisattelse og subjektiviteten. Politisk Revy.

\section{Noter}

1 (Hermansen 2002a,b,c,d, 2003a,b,c,d,e,f,g,h, 2004a,b; Hermansen \& Herløv Petersen 2003; Hermansen \& Jensen 2004; Hermansen, Løw \& Petersen 2004; Hermansen \& Petersen 2002).

2 Et par referencer i den omfattende litteratur om tværfaglighed er Nielsen (1976) og Kristensen (1991).

3 For videre uddybning, se (Hermansen 2003g). 